\title{
A Comparative Survey on the Cultivated Area and Wild Trees in Ninety Villages in Virudhunagar District
}

\author{
K Selvaraj* \\ Sri Kaliswari College, India
}

Submission: July 17, 2017; Published: October 23, 2017

*Corresponding author: K Selvaraj, Sri Kaliswari College (Autonomous), Sivakasi-626130, Virudhunagar District, Tamilnadu, India, Tel: 9789240653; Email: kselvarajphd@gmail.com

\section{Abstract}

A survey was made in ninety villages during April 2017 to May 2017 on the agricultural crop, cultivated area and wild trees available now and in the past. From this survey it was observed that the cultivated area have diminished than in the past. The agricultural crops were changed. In the past, in most of the villages, Paddy and Pulses were cultivated but now cotton and vegetables are cultivated. This change in the crop pattern was made due to the water scarcity. In the past Sugarcane, cultivation was much pronounced in most of the villages, but now there is no sugarcane cultivation because of climate changes and low yield. The wild trees were found to be decreased than in the past. Some villages had small forests in the past, which were defaced. This reflected on the usage of fuel for cooking. Though people do not depend on tress for fuel, the cultivable lands have been converted into residential areas due to urbanization with no awareness for environment. Further, the survey indicates a pitiable situation that the villagers are not having any interest to take up farming, due to industrialization and urbanization.

\section{Introduction}

Environment is our heritage. Our forefathers handed down a wealthy and healthy environment. It is unethical to pass on a polluted and degraded environment to our successors. Since the beginning of human civilization, man has been interfering with the environment, resulting in the environmental crisis or ecocide [1]. In Virudhunagar District villages, the agricultural area has decreased because of the population growth and urbanization. Fifty percent yield got decreased and forty million people reel under of undernourishment [2]. Due to the mining and quarrying activities in the last fifty years 900 million hectors of land have undergone desertification all over the world [3]. Many wild forests present in the past were the natural sources of the village. During the urbanization many village forest were destroyed. Industries are the main pollution causing centers. When an industry comes up near the agricultural area the nearest cultivated area has been affected with poor yield. In Virudhunagar District alone in the past thirty years many industries have comes up in the cultivated area and yield got decreased.

\section{Methodology}

In Virudhunagar District ninety villages were selected randomly for this survey. A survey was made during April 2010

to May 2010. Twenty five to forty people who are aged above fifty were selected in each village and asked questions from our prepared questionnaire.

\section{Results and Discussion}

The survey results have been tabulated in Tables 1-4.

Table 1: Area under agricultural crop cultivation (Total surveyed 90 villages).

\begin{tabular}{|c|c|c|c|c|c|}
\hline Cultivable Area & $\mathbf{1 0 0 \%}$ & $\mathbf{7 5 \%}$ & $\mathbf{5 0 \%}$ & Below 50\% & No Cultivation \\
\hline Past & 62 & 24 & 4 & - & - \\
\hline Present & - & 4 & 7 & 73 & 6 \\
\hline
\end{tabular}


Table 2: Agricultural yield (Total surveyed 90 villages).

\begin{tabular}{|c|c|c|c|c|c|}
\hline Yield & Very High & High & Medium & Poor & No Yield \\
\hline Past & 18 & 66 & 6 & - & - \\
\hline Present & - & - & 7 & 69 & 14 \\
\hline
\end{tabular}

Table 3: Village forest (Total surveyed 90 villages).

\begin{tabular}{|c|c|c|c|}
\hline Village Forest & Available & Non-Available & Destroyed \\
\hline Past & 67 & 23 & - \\
\hline Present & 27 & 23 & 40 \\
\hline
\end{tabular}

Table 4: No. of Wild trees (Total surveyed 90 villages).

\begin{tabular}{|c|c|c|c|c|}
\hline Wild Trees & $\mathbf{1 0 0 \%}$ & $\mathbf{5 0 \%}$ & Below 50\% & Destroyed \\
\hline Past & 80 & 10 & - & - \\
\hline Present & - & 40 & 46 & 4 \\
\hline
\end{tabular}

The survey clearly indicates that the cultivated areas rapidly decreased from the past. In some villages such as Menampatti, Narayanapuram, Pallapatti and Viswanatham there is no cultivation now, due to the urbanization and industrialization and the cultivated lands have become residential plots and industries. In other villages too the cultivated land decreased. For example, 450 achres of land used for cultivating plants have now become only 200 achres. The agricultural crops have also changed now. In the past in villages such as Pusaripatti, Karthikaipatti, Malliphuthur, Reddiyapatti, Anuppankulam, Nallanchettipatti, Thayilpatti and Kellapotalpatti Paddy was main crop but now no cultivation of Paddy because of the water scarcity and nearest ponds have low water level and dried in condition. In some other villages such as Ayyampatti, Appayanaickerpatti, Vellakulam and Kansapuram where Sugarcane was cultivated, extensively have now only cotton and vegetables because of climatic change and less water requirement.

In the past, the agricultural yield was very high but now it got reduced substantially because of the land becoming sterile due to the industrial pollution. As the yield becoming less, the farmers are not interested in farming which is also one of the reasons for the increase in non-cultivable areas.
In the past all villages had small forest and wild trees. Which decreased rapidly and in some of the villages such as Malli, Appayanaikarpatti, Kelaperumalpatti, Kannicherypudur, Vishwanatham, Puthupatti and Ayyanarpuram the forest got completely disappeared. Change in lifestyle pattern of using LPG for cooking also caused the lack of interest in vegetation maintenance among the people.

\section{Conclusion}

Urbanization and industrialization are the main reasons for climatic changes and change in crop pattern. In Virudhunagar District the change in the agricultural crop, reduction in cultivable area and loss of forest are mainly due to urbanization and industrialization

\section{References}

1. Thangamani A, Thangamani S (2006) Elements of Environmental studies. Shrishti Impression, Coimbatore, India, pp. 9-10.

2. Sathaye J, Shukla PR, Ravindranath NH (2006) Climate change, sustainable development and India: Global national concern. Curr Sci 90(3): 314-325.

3. Dhar BB (2000) Mining and environment. APH Publishing Corporation, New Delhi, India, pp. 10- 12.

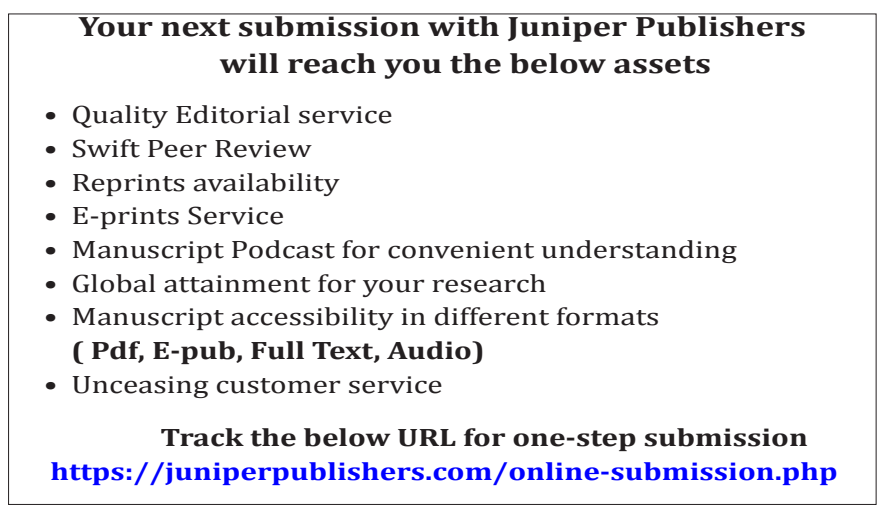

